\title{
CHIMERAS AND MERISTEMS
}

\author{
F. A. L. CLOWES \\ Department of Botany, University of Oxford
}

Received 5.iv.56

\section{SHOOT APICAL MERISTEMS}

In the higher plants most of the longitudinal growth and often much of the latitudinal growth takes place at the apices of shoots and roots. Because of this and the fact that plant embryos are difficult subjects for experiments, the arrangement and behaviour of the dividing cells of the apex have interested botanists for the last hundred years. The cells cannot be seen dividing so their planes and frequencies of division have to be inferred from such observations as the arrangement of cells, the thickness of cell walls, and by less direct means. Some of these last depend upon the interpretation of chimeras, which may be variegated plants, or graft hybrids, or have cells with different chromosome complements, and recently work on the apices of chimeras has produced several useful results.

Chromosome chimeras have been noted in roots (Navaschin, 1927; Kachidze, I932 ; Juhl, I953), but their stability is uncertain and it is in shoots, where the cell arrangement is more difficult to interpret, that the work has been useful.

In median sections of the apices of most plants there are layers of cells parallel to the surface. There are two theories about these layers. Hanstein's histogen theory assumed that the layers were tissuespecific, and separated them according to whether they gave rise to the epidermis, or cortex, or stele. This theory is not useful except for roots and some anomalous shoots because the pattern of layers is upset in the formation of leaf primordia and their vascular connexions. Modern views on shoot apices are dominated by a modified form of the tunica-corpus theory originally put forward by Schmidt (1924). This divides the meristem above the leaf primordia into an outer tunica of one or more layers where cell divisions are anticlinal, perpendicular to the surface, and an inner corpus where the dividing walls may be either anticlinal or periclinal or in any other plane. The corpus and each of the tunica layers, being independent of each other, behave as germ layers in the sense used by embryologists, but they are not histogens, that is, they are not tissue-specific.

Early workers thought that the number of tunica layers was constant, but most now recognise that it may vary with the age of the plant and the phase of the plastochron, the period of time between the formation of one leaf and the next. The theory depends upon the fact that a solid body, growing throughout, must increase its surface greatly in order to accommodate its increasing volume. The outer cells of a shoot apex accommodate this surface expansion by 
anticlinal divisions. It is therefore to be expected that there will be a gradual increase in the predominance of anticlinal divisions away from the centre. Similarly the wider the apex becomes in each plastochron and in the life of each shoot the greater will be the number of layers dividing only anticlinally.

For these reasons it is often impossible by inspecting sections to say certainly how many tunica layers there are in a meristem. Nevertheless the tunica-corpus theory is a useful, simplified way of describing the behaviour of most Angiosperm shoot apices. There are, however, certain seed plants which do not have layered apices and to them it cannot be applied. In these the outer cells divide anticlinally and, in addition, periclinally and thus produce anticlinal rows of cells. The apex then appears like a fountain as in some cycads, or is irregular where periclinal divisions are rarer as in some conifers and Monocotyledons (Thielke, I954).

At best the tunica-corpus concept describes only one aspect of the behaviour of cells in an apex above the youngest leaf primordia. Superimposed on the layering there are patterns of rates of mitosis and differentiation which give rise to various zonations. Where the tunica consists of more than one layer, periclinal divisions usually do occur in its inner layers in the formation of leaf primordia. The number of cell layers which go to form the leaves varies with the species.

\section{CHIMERAS}

Chimeras can arise spontaneously or can be induced by mitotic poisons or by grafting. Many cultivated plants once thought to be polyploid are now known to be chimeras (Blaser and Einset, I948; Einset and Lamb, I95I ; Dermen, I95 I $a$ ). Those used in developmental anatomy are either spontaneously variegated or spontaneous or induced partial polyploids. Green plastids can mutate under direct or indirect nuclear control and produce colourless or pale plastids (Darlington and Mather, I950). Plastids divide and grow and are passed to each cell generation with the cytoplasm. They are not necessarily divided equally between sister cells so that a cell with both green and colourless plastids can give rise to tissues whose cells contain only green or only colourless plastids. Variegated chimeras arise in this way. Some tissues do not develop chlorophyll even if the cells inherit potentially green plastids and variegation may result from causes other than inheritance of different kinds of plastids. In nature variegated chimerical seedlings do not usually survive, but in cultivation they and chimerical branches are often preserved and propagated.

Polyploid chimeras have to be examined microscopically for chromosome number, cell size, or nucleolus number. They are better than variegated chimeras for interpreting apices since the chimerical structure can be seen in sections of the apex as well as in the leaves. 
In Panicum and other plants which have leaves produced from the outer layer of the tunica only (Thielke, I95I), stable, variegated periclinal chimeras could not be detected if they exist.

\section{CHIMERICAL MERISTEMS}

The polyploid chimeras produced by treatment of buds or seeds with colchicine are periclinally arranged and sometimes sectored as well. Their stability appears to vary with the species. Satina, Blakeslee and Avery (1940) produced periclinal chimeras in Datura shoots which appeared perfectly stable. Their plants had two tunica layers and they found three germ layers which were diploid, tetraploid or octoploid in various arrangements. One germ layer is the outer tunica layer, the second is the inner tunica layer, and the third is the corpus, and these remained completely independent. Baker (I943) obtained similar results in Solanum which has a single tunica layer and therefore two germ layers. Dermen ( 1947 and I953a) found that in Oxycoccus and Prunus persica the germ layers were not so stable. In both plants there were normally three germ layers and the innermost could have both diploid and tetraploid cells presumably because the middle layer divided periclinally occasionally. In Prunus particular tissues could vary in their derivation.

Variegation can be maintained by both periclinal and sectorial forms of chimera. The behaviour of the apex of such plants has to be interpreted from the colour pattern in the leaves because plastids cannot be distinguished in the apices. Plants with leaves whose margins are of different colour from the centres are nearly always periclinal chimeras. Renner and Voss (1942) showed that Prunus pissardii var. Hessei was like this. The white margin is due to the periclinal division at the margin of the epidermis which is without green plastids. Pelargonium Freak of Nature is similar, but with a green margin round a white centre.

Thielke (I954) has recently obtained valuable results from whiteover-green variegated chimeras in the Commelinaceæ. In Commelina benghalensis var. foliis variegatis, a plant having pale green leaves with white margins and also white stripes running into the tip, she showed that the outer layer of the tunica produced the leaf epidermis, the inner tunica layer produced the subepidermal layer of the mesophyll, and the corpus produced the central mesophyll in the green areas. The plant is a white-over-green periclinal chimera. The pale green parts of the leaf have chlorophyll in the central mesophyll and practically none in the outer mesophyll and epidermis. The white parts are due to a normal and an abnormal cause. At the white leaf margin the absence of underlying green tissues is caused by the normal absence of corpus derivatives, as in Prunus pissardii. The white stripes are due to the abnormal absence of corpus derivatives and the abnormal multiplication of the inner tunica layer, in other words, to a breakdown of the regular layering. 
Tradescantia fluminensis var. albostriata is also a periclinal chimera and it is of similar appearance. Nevertheless, its apex behaves differently from that of Commelina. There is no tunica in some shoots, for some of the outer cells divide periclinally. The leaf primordia are formed sometimes from cells wholly derived from the outer layer and sometimes from inner tissue as well. The white stripes in the leaves are derived wholly from the outer layers and the green stripes are derived from inner tissue with one or two layers of the outer tissue. The leaf primordia in Tradescantia and many other Monocotyledons are very broad and allow sectors of one leaf to be constructed in different ways. The plant then is a periclinal chimera which is secondarily sectored.

Tradescantia albiflora var. albovittata is a periclinal chimera which is sectored primarily, i.e. mericlinal (Thielke, I954). There is a single tunica layer and the cells of the corpus are arranged in regular horizontal rows between the distichous primordia. These rows remain discrete even in the leaf primordia and allow the leaf to have longitudinal stripes, each stripe derived from a cell which is genetically different from cells of the adjacent stripes. The single-layered tunica forms the epidermis only, and as this has no chlorophyll except in the guard cells, it does not obscure the white stripes. Axillary shoots from variegated plants of this species can be wholly white or wholly green because the angle subtended by the bud is smaller than that subtended by the axillant leaf.

Zebrina pendula var. quadricolor is similar except that the stripes are broader because the corpus cells are larger in relation to the width of the apex than in Tradescantia albiflora. Thielke (1955) has also described a variegated chimera of Hemerocallis where the origin of the sectoring in the discrete rows of cells of the corpus is particularly clear.

\section{SIGNIFICANCE OF CHIMERAS FOR NORMAL ONTOGENY}

The use of chimeras to investigate the behaviour of meristems must be subject to two important corrections.

(I) The chimerical form may behave differently from the normal form. There is plenty of evidence for this. The crumpled appearance of the leaves of some chimeras is presumably due to poor co-ordination in growth rates of the various layers. In the polyploid chimeras the larger polyploid or aneuploid cells may divide at different rates from diploid cells. Also the different kinds of cells need not compete in the same way as cells of a genetically homogeneous tissue. Dermen ( $1953 a$ ) in fact showed that the stability of the chimera depends upon how the diploid and tetraploid cells were distributed among the three germ layers in Prunus persica. In his material most of the chimerical types were not permanent, but those with the $2 n-4^{n-4} n$ and $4 n-2 n-2 n$ arrangement were usually stable. It is especially important 
to look for anomalous behaviour of meristems in studies on the homology of organs (Satina and Blakeslee, 1941, 1943; Dermen, $1953 b)$.

In the variegated chimeras, too, there is evidence that cells that produce white or yellow tissues differ from those that produce green tissues not only in the primary chlorophyll difference, but also in secondary respects. In Commelina benghalensis the inner layer of the tunica of variegated plants consists of cells which are more elongated tangentially than those of the green plants. In this species, and in other members of the Commelinaceæ described by Thielke (1954), the leaf palisade cells were of different shapes in the green and yellow parts of the leaf. In Prunus pissardii the leaf epidermis divides periclinally and anticlinally in the variegated chimera, but only anticlinally in the normal form (Renner and Voss, 1942). In Pelargonium Freak of Nature the epidermis divides periclinally and anticlinally when there is yellow tissue underneath, but only anticlinally in green leaves, or in leaves where there is only a small central yellow patch, or in shoots which have lost the potentially green outer layer (Thielke, 1948). In Sanseviera the leaf margin can produce roots when it is green, but not when it is colourless except after applying indole acetic acid (Thielke, I948). A more striking difference between a normal and a chimerical plant occurs in Tradescantia fluminensis var. albostriata. Variegated plants usually, but not invariably, have the anomalous apical structure described above. Wholly green shoots usually, but not invariably, have a normal one-layered tunica.

(2) Variegation in certain exceptional chimeras may be due not solely to the chimerical structure, but partly to physiological gradients. The possibility that this might be so can be seen in Thielke's paper on Hemerocallis. Her plants were mericlinal chimeras, and the single tunica layer, dividing anticlinally only, should not have shown the sectoring. Yet she found that the guard cells were not clearly green when over yellow mesophyll, but were green over green mesophyll. A similar bleaching effect on green tissue has been reported for the yellow tissue of some Pelargonium chimeras (Chittenden, 1927). The green flecks sometimes found in white tissue of Pelargonium Freak of Nature could be due to physiological causes though they are usually interpreted as due, either to islands of meristematic activity in the epidermis, or to their being mericlinal chimeras with a few green cells scattered in a white apex (Jones, 1934).

However, much useful information about the behaviour of apices can be found by studying chimeras. The fact that stable periclinal chimeras exist at all shows that the tunica layers are independent of each other and of the corpus. An understanding of the mechanical basis of the tunica-corpus theory leads us to expect variation in the stability of periclinal chimeras, and this is what is found. Some plants like Datura are perfectly stable ; others are only partially so, and instability is always strongest in the inner layers. It was once 
thought that the plants without a tunica could not produce stable periclinal chimeras and this accounted for their rarity in conifers, but Thielke has shown that periclinal divisions in the outer layer of the apex do not prevent a periclinal arrangement from becoming stable so long as there is a genetic discontinuity between two other layers of the apex.

This view has been criticised by Hejnowicz (1956) who wrongly supposes that periclinal divisions in the outer layer must eventually contribute to the corpus and so cause the shoot to become nonchimerical. Hejnowicz has also reported the existence of unstable periclinal chimeras in a conifer, Funiperus sabina. Its apparently green shoots have a white surface layer, and the chimera is unstable because the white surface cells divide periclinally at the apex and so invade the green inner tissue producing, first, a mericlinal chimera with white sectors and, later, a wholly white shoot. The plant does not lose its chimerical character because many new chimerical branches arise from the periclinal or mericlinal parts of shoots.

Another point of interest arises from the colchicine-induced polyploid chimeras. Their polyploid cells must always be derived from the frustration of anaphase in a cell which is undergoing mitosis. The polyploid germ layers are most likely derived from single mutant cells. These divide and their progeny take over the whole of the germ layer. This is also what happens when a non-chimerical shoot is produced from an unstable periclinal chimera (Dermen, 195 $1 b$ ). According to a recent French theory on the behaviour of apices the apical cells of the tunica do not divide and do not give rise to any new tissue at all in vegetative apices (Buvat, 1952, I953 ; Lance, 1952, 1953). This cannot be true of periclinal chimeras such as those of Datura. The mutating cells which produce the polyploid germ layers must have been dividing during the colchicine treatment, and even if they were on the flanks of the meristem their progeny must divide at the apex in colonising the whole of the germ layer.

Another contribution to our knowledge of apices comes from Thielke's demonstration that the arrangement of cells as seen in transverse sections does reflect accurately the planes of their division. She showed (Thielke, 1954) that in the Commelinaceæ only those species with horizontal rows of cells in the apices between the distichous leaf bases produced mericlinal chimeras. It is interesting that among closely related plants there should be such diversity in the behaviour of the apical meristem. Mericlinal chimeras are often not stable in plants with a well developed tunica (Dermen, 1945). Meristematic activity tends to convert them to periclinal chimeras or to non-chimeras as might be predicted on the tunica-corpus theory. But in the Monocotyledons studied by Thielke the peculiar behaviour of the meristem associated with the distichous leaves subtending wide angles at the shoot axis preserves the stability of the sectorial pattern even when there is a tunica. 


\section{SUMMARY}

I. Work on chimeras has been used in the study of the behaviour of shoot apical meristems.

2. The origin of periclinal chimeras shows that cells at the apex of meristems do divide and form tissues.

3. Some plants have discrete and therefore stable germ layers as predicted by the tunica-corpus theory. Others have unstable germ layers.

4. Stable germ layers can exist even in meristems without a true tunica : the germ layers are then usually unstable, causing periclinal chimeras to become, first, mericlinal, and then non-chimerical.

5. The normal instability of mericlinal chimeras, predicted by the tunica-corpus theory, is absent in meristems whose cells divide only in one of the longitudinal planes.

Acknowledgment.--I am indebted to Professor C. D. Darlington for his encouragement and help in writing this review.

\section{REFERENCES}

BAKER, R. E. I943. Induced polyploid periclinal chimeras in Solanum tuberosum. Amer. J. Bot., 30, 187-195.

BLASER, H. W., AND EINSET, J. I 948 . Leaf development in six periclinal chromosomal chimeras of apple varieties. Amer. F. Bot., 35, 473-482.

BUVAT, R. I952. Structure, évolution et fonctionnement du méristème apical de quelques dicotylédones. Ann. Sci. nat. Botanique, 2nd Ser. 13, 198-300.

Buvat, R. I953. L'apex de Triticum vulgare; modalités de reprise des mitoses lors de la germination et du fonctionnement végétatif. C.R. Acad. Sci., Paris, 236, I989-I 99 I.

ChItTENDEN, R. J. I927. Vegetative segregation. Bibliogr. genet., 3, 355-442.

Darlington, c. D., And Mather, K. I950. Genes, Plants and People. London.

DERMEN, H. I945. The mechanism of colchicine-induced cytohistological changes in cranberry. Amer. F. Bot., 32, 387-394.

DeRmen, H. I947. Periclinal cytochimeras and histogenesis in cranberry. Amer. J. Bot., 34, 32-43.

DERMEN, H. I 95 I $a$. Ontogeny of tissues in stem and leaf of cytochimeral apples. Amer. F. Bot., 38, 753-760.

DERMEN, H. I $95 \mathrm{I} b$. Tetraploid and diploid adventitious shoots from a giant sport of McIntosh apple. F. Hered., 42, I 45-I 49 .

DERmen, H. I953a. Periclinal cytochimeras and origin of tissues in stem and leaf of peach. Amer. 7. Bot., 40, 154-168.

DERMEN, H. I $953 b$. The pattern of tetraploidy in the flower and fruit of a cytochimeral apple. F. Hered., 44, 31-39.

EINSET, J., AND LAMB, B. I95I. Chimeral sports of grapes. F. Hered., 42, I59-162. HEJNowicz, z. I956. The first periclinal chimera among Gymnosperms. Acta Soc. Bot. Polon., 25, 181-202. (In Polish with English summary.)

Jones, w. N. 1934. Plant Chimaeras and Graft Hybrids. London.

JUhL, H. 1953. Über zwei spontane Änderungen der Chromosomenzahl in Gramineen-Wurzeln. Ber. dtsch. bot. Ges., 66, 289-295.

KACHIDZE, N. 1932. Changes in the chromosomes and formation of chromosome chimeras under the influence of X-ray treatment of Cephalaria syriaca. Bull. appl. Bot. Pl.-Breed., 2nd Ser. I, I 77-187. (In Russian.)

LANCE, A. 1952. Sur la structure et le fonctionnement du point végétatif de Vicia faba L. Ann. Sci. nat. Botanique, 2nd Ser. 13, 301-339. 
LANCE, A. I953. Sur l'absence d'initiales apicales et la configuration de l'anneau initial chez Vicia faba L. C.R. Acad. Sci., Paris, 236, 5 I0-51 2.

NAWASchin, M. I927. Variabilität des Zellkerns bei Crepis-Arten in Bezug auf die Artenbildung. Z. Zellforsch., 4, I 7 I-2 I 5 .

RENNER, O., AND voss, M. I942. Zur Entwicklungsgeschichte randpanaschierter Formen von Prunus, Pelargonium, Veronica, Dracaena. Flora, 135, 356-376.

satina, s., AND Blakeslee, A. F. 194I. Periclinal chimeras in Datura stramonium in relation to development of leaf and flower. Amer. F. Bot., 28, 862-87 I.

satina, s., AND Blakeslee, A. F. 1943. Periclinal chimeras in Datura in relation to the development of the carpel. Amer. F. Bot., 30, 453-462.

SATINA, S., BlakesleE, A. F., AND AVERY, A. G. 1940. Demonstration of the three germ layers in the shoot apex of Datura by means of induced polyploidy in periclinal chimeras. Amer. 7. Bot., 27, 895-905.

SCHмIDT, A. 1924. Histologische studien an Phanerogamen Vegetationspunkten. Bot. Arch., 8, 345-404.

THIELKE, C. 1948. Beiträge zur Entwicklungsgeschichte und zur Physiologic panaschierter Blätter. Planta, 36, 2-33.

THIELKE, c. r95 I. Über die Möglichkeiten der Periclinal-chimärenbildung bei Gräsern. Planta, 39, 402-430.

THIELKE, C. I954. Die histologische Struktur des Sprossvegetationskegels einiger Commelinaceen unter berucksichtigung panaschierter Formen. Planta, 44, 18-74.

THIELKE, C. 1955. Die Struktur des Vegetationskegels einer sektorial panaschierten Hemerocallis fulva L. Ber. dtsch. bot. Ges., 68, 233-238. 